\title{
The Role of Majelis Ulama Indonesia and Its Fatwas within The Indonesian Governance System
}

\author{
Yudi Widagdo Harimurti ${ }^{1}$, Encik Muhammad Fauzan ${ }^{2}$, Indah Purbasari ${ }^{3}$, Indra \\ Yulianingsih ${ }^{4}$ \\ \{yudi.harimurti@trunojoyo.ac.id ${ }^{1}$, encik.fauzan@trunojoyo.ac.id ${ }^{2}$, indah.purbasari@trunojoyo.ac.id ${ }^{3}$ \\ indra.yulianingsih@trunojoyo.ac.id $\left.{ }^{4}\right\}$
}

Universitas Trunojoyo Madura, Jalan Raya Telang PO BOX 2 Kamal-Bangkal-East Java-Indonesia ${ }^{1}$, Universitas Trunojoyo Madura, Jalan Raya Telang PO BOX 2 Kamal-Bangkal-East Java-Indonesia ${ }^{2}$, Universitas Trunojoyo Madura, Jalan Raya Telang PO BOX 2 Kamal-Bangkal-East Java-Indonesia ${ }^{3}$, Universitas Trunojoyo Madura, Jalan Raya Telang PO BOX 2 Kamal-Bangkal-East Java-Indonesia ${ }^{4}$,

\begin{abstract}
Ulema are the topnotch scholars in Islamic religious teaching trusted by all levels of Muslim communities to guide their life and there is the Indonesian Ulema Council also known as MUI. In practice, MUI plays a significant role to Muslims and the government and it serves as a guidance in resolving peoples' problems related to religion.Therefore, this study is conducted to elaborate the existence of MUI within the Republic of Indonesia's governance system and how it should be managed.within the system. Moreover, the method used in this analysis is the normative research method. The approach used is a statute (legislation) and historical approach. These results indicate the significant role of MUI in the Republic of Indonesia's constitutional system as expressed in MUI fatwas that are considered as parts of some Laws, and the government references in decision makings. Hence, MUI should be the part of the Ministry of Religious Affairs.
\end{abstract}

Keywords: Fatwa, Management, MUI, Governance.

\section{Introduction}

The Indonesian Ulema Council ( known as MUI) is a Nonprofit Organization that caters ulema, zua'ama (leaders) and Islamic scholars to guide, mentor and protect Muslims over the country. As a consultative council for ulema, zua'ma and Islamic scholars, MUI seeks to:

a. provide guidance and mentoring to Indonesian Muslims by manifesting religious and social permitted by God, Allah SWT;

b. provide advice and fatwas related to religious and social matters to the government and society, improve activities oriented to achieving the building of Ukhuwah Islamiyah and inter religion harmony seeking to reinforce the national unity and solidarity ;

c. function as an intermediary between ulema and the government as well as interpreters between the government and the Muslim society and conversely in favor of the national development.

Furthermore, MUI is basically a non governmental organization to the extent that its operation has no relevance with the state establishment. MUI existence within the the Republic of Indonesia's governance system according to Laws Number 17 of 2013 on Social 
Organizations thereafter called as UU Ormas. Hence, MUI has no relevance nor obligation to take part in the state establishment.

Nonetheless, in practice, MUI at times have taken parts in governing the state, particularly in regard of issuing fatwas to justify numerous matters related to the governance and Islamic society. Numerous fatwas are exercised in some laws and regulations regarding Sharia issues, narcotics, banking, benefaction, pornography and others. In addition, MUI fatwas serve as a guideline in decision makings despite its less binding power imposed on society.

\section{Methods}

A normative or doctrinal legal research is likely conducted in the study. It is a study carried out seeking to list positive law, fundamentals and positive legal philosophy as well as in concreto legal findings exercised in particular legal matters"[1]. While the aim of the study is to resolve problems. Thus, the government is demanded to establish judicial and theoretical foundations in its governance as ways to specify MUI participation in running the state of Indonesia.

This study uses several approaches based on its research objects. First, the statute approach which literally means that all regulations related to legal matters be explored and ratio legis findings need to be highlighted prior to the birth of laws "[2]. The statute approach is used this since it focuses on numerous legislation related to MUI such as Laws, State Regulations, President Regulation President Decrees.

\section{Result and Discussion}

As judicial issues emerged as MUI fatwas are definitely not regulations, thus binding legal power is absent. Ironically MUI fatwas have played a considerably important role to society and and the government albeit in reality it is not a state institution. Rather, it is merely an NGO whose function like that of the House of Representatives (thereafter abbreviated as DPR) as a policy maker or functions as norm creator and apply the norms simultaneously [3].

One of the MUI fatwas used as a guideline within the state operation is expressed in Laws Number 21, 2008 on Sharia Banking (thereafter called as Sharia Banking Laws). Article 26 section (1) f Sharia Banking Law describes " Business activities mentioned in Articles 19, 20 and 21 and or Sharia products and services comply with the Sharia Principles. Furthermore, Article 26 section (2) states that the Sharia Principles mentioned in section (1) is formulated through MUI fatwa".

The following Laws are Number 19, 2008 Laws on National Sharia Securities Laws (hereafter called Laws of NSS) that mainly focus on Section 25. The Laws of NSS Number 33, 2014 focus on Halal Product Guarantee (hereafter called Laws of HPG) and Number 40, 2014 Laws focus on Insurance ( hereafter called Laws of Insurance) specifically Article 1 section (3).

MUI fatwas included within Sharia Banking Laws can be specifically be seen on Article 25 which states that " in efforts to issue National Sharia Securities (NSS), the Ministry of Religious Affairs sought fatwas or justifications of MUI to make NSS acceptable to Sharia principles. MUI was considered as an authorized institution entitled to issue fatwas related to 
sharia principles. Article 25 clearly defines that " the authorized institution to establish fatwas regarding sharia principles is MUI or other institutions appointed by the government".

Additionally, MUI fatwas contained in the Laws of Halal Product Guarantee on Article 1 state that "halal certification is recognition over the warranty of halal products issued by the authorized institution responsible for issuing warranty of halal products based on written fatwas issued by MUI. Article10 claims that "MUI is in charge of auditing halal certifications, establishing warranty of halal products and issuing Accredited Halal Product Labels". While MUI fatwas written in the Laws of Insurance on Article 1 section (3) mentions that "Islam Sharia Principles are Islamic law principles exercised within the insurance business activities on the basis of fatwas issued by the authorized institutions responsible for establishing fatwas related to sharia principles".

Undoubtedly, those four Laws have proven that MUI has played a significant role in the Indonesian Governance System despite lacking of legal power and hierarchy in legislation. Fatwas simply function as advice rather than laws. Thus, society can opt between using fatwas as guidance or simply ignore them.

In running the organization and its functions, the members of MUI Fatwa Commissioner are also assisted by the Daily Operatives of MUI Head Council. All MUI fatwas issued by the MUI Fatwa Commissioner are grouped into several categories from which there are sections of Aqidah and Islam Sects, Worship, Society and Cultures, Food Products, Drugs, Science and Technology.

Subsequently, MUI fatwas turned into society guidelines as responses to problems closely related to religious matters. As an institution MUI is formally seen as non partisan and holds no affiliation towards particular political powers. The government 's major supports to MUI is clear in terms of its acceptance and adoption of MUI fatwas for the state governance especially dealing with religious issues over Islam blasphemy and MUI halal warranty certification.

Along with its significant role, MUI likely enhances its existence within the state governance as a large number of MUI fatwas have been issued since its establishment in 1975. There were 137 fatwas ,collected from 1975 to 2011, illustrated in MUI book published in 2011 whose title was "Himpunan Fatwa MUI Sejak Tahun 1975". The National Sharia Council of MUI ( hereafter called NSC MUI) from which approximately 174 fatwas concerning Sharia Financial Institutions were also issued as the basis of Islamic financial institutions.

Furthermore, MUI 's role within the state governance can be found in the issuance of halal certification by the institution of Food Product, Drug and Food Research ( hereafter called LPPOM MUI). LPPOM MUI stated that the halal warranty of food products, drugs, cosmetics, and other respective products in accordance with Islamic principles. The certification is a prerequisite to acquire halal label attachments on product containers issued by halal certification institutions. However, the authorized institution has been delegated to the Executive Body of Halal Product Warranty Issuance on the basis of Laws of Hall Product Guarantee

Apart from its involvement in the halal food certification, MUI also established 10 fatwas denoting freedom of religion issues and 8 fatwas related to religion and sects grouped separately in Aqidah Section and Religion and Sect Section. The ten fatwas have so far been applied to connote whether any religious activities conducted by numerous sects under Islam laws as "misleading and leading people to violate against Islamic fundamental principles" [4]. One of the famous fatwas was concerning a sect who called themselves the Jama'ah 
Muslimin Hizbullah (community of Hizbullah Muslims) and their teaching on Jama'ah, Khalifah dan Bai'ah.

MUI fatwas also served as a legal basis to resolve conflicts as a response toward Basuki Tjahja Purnama also known as Ahok related blasphemy of Al Qur'an related to a revelation stated in the Qur'an Surah Al Maidah verse 51 to which he took it as a deception for it clarifies that Muslims should never appoint Christians nor Jewish to serve as a leader within the Muslim society. Inevitably, Ahok allegedly committed a defamation against the Qur'an as issued by MUI through its fatwa and announced publicly on October 11, 2016. MUI asserted that the Governor of DKI Jakarta was charged for defamation against the Qur'an as well as the ulema, thus a legal sanction be imposed on him. Under these circumstances, MUI recommended that the government through its officials as legal measures to put Ahok to trial quickly, proportionally and professionally as an individual personally gave the Qur'an and Islam religious teaching a bad reputation. Despite its significance, MUI simply had no biding legal power to be exercised in such legal matter since it operated as an NGO rather than a State Institution.

MUI is grouped in The Sosio Political Sphere and interest groups are groups of people building the brotherhood with others whose interests are the same Gabriel A.Almond, classified the groups as: Interest Group Association, Institutional Interest Groups and Non Association Interest Group. Meanwhile, MUI is listed in the Association Group of Interests for this group is established in favor of a particular group's interests within the society or social group mainly for the Muslim society. Such group of Interests are NGO wherein MUI is not classified as a state institution.within the structure of the Government Political Sphere.

Decisions with binding legal power exist within decisions granted by MPR, DPR and DPD. Yet, MUI is included in The Socio-Political Sphere namely the group of interests that literally refer to each enactment issued by the MUI that barely contains legal power and it is up to the society as to whether they comply with the fatwas or leave them behind. MUI Fatwas related to the state have been influential, it is obvious that MUI existence within the state governance is essential.

Moreover, evaluations and managements over the MUI existence within the Indonesian Governance System are highly needed. As such, all MUI products accommodate the government necessities, for instance, in issuing the Halal Certificates as well as Sharia Fatwa from which some laws are made and they have binding legal power Rianto Nugroho stated that evaluations are highly needed "to figure out the gaps between expectation and reality" [5]. Therefore, this evaluation is needed to see whether the MUI has met the objectives and benefits of its establishment. Therefore, evaluation must be carried out not only at the end of policy making, but must be carried out in the entire policy making process. Policy evaluation is an objective, systematic, and empirical evaluation carried out on the impact of the applicable policy and the objectives of the intended target [6].

On the policy evaluation, results and implications shall appear as to whether they have met the expectation or not. Thus, it means that the enacted policies have succeeded or failed in achieving the goals and the ways to maintain the policies and solutions in case the policies fail to meet the target and ways to sustain the effects. In addition, "evaluation on policies serve as the basis of the existing policies whether they are continued, revised or stopped completely".[7]

Upon the evaluation, the government needs to organize the existence of MUI which influences the state governance and Muslim activities in Indonesia. Several methods in governing state institutions are described as follow, namely: [8] a) By maintaining state institutions whose managements are beyond the 1945 Indonesian Constitution by giving them 
the right and precise as well as using the proper stipulations forms as the legal basis of of the state establishment; b) By combining or galvanizing numerous unorganized regulations withing the 1945 Indonesian Constitution as the basis for establishing the state institution; c) By becoming part of the state institution as managed in the 1945 Indonesian Constitution or the state ministry under which institutions organized beyond the 1945 Indonesian Constitution; d) By liquidating some institutions wherein their managements are organized beyond the 1945 Indonesian Constitution; and e) By understanding several managements of the state institutions, thus, an analogy can be applied to refer to MUI and Ormas management. It turns out that MUI has the most suitable management and considered as the most proper institution. Hence, once MUI registered as the state institution a sync is created between both institutions.

MUI, in this regard, works on a specific function related to matters in Islamic field, and it is suggested that MUI be the part of the ministry of religious affairs that handles religious matters wherein Islam as a religion is included. By appointing MUI as part of the ministry of religious matters, the government should be able of minimizing operating budget and carrying out functions, duties and authorities more efficiently.

\section{Conclusion}

MUI, along with its fatwas, plays an integral role in establishing the state governance despite its category as an NGO (Ormas). However, judicial issues emerged as to whether MUI holds a legal power and the MUI fatwas bind the society within the state, more importantly the life of Muslim society.

The MUI should be managed in such a way that it subsequently gain legal power seeking to enhance MUI fatwas existence in running the state of Indonesia as well as in its governance system. In this regard, MUI should be made as part of a State Ministry. In the extent that MUI works as part of the Ministry of Religious Affairs , a great collaboration should be created between MUI with the Ministry of Religious Affairs. Despite its category as an NGO, MUI has a specific function related to Islamic matters. Thus, suggestions arise within the Muslim society that MUI should be made an state agency assisting the Ministry of Religious Affairs`

\section{References}

[1] B. Sunggono, Metode Penelitian Hukum. Jakarta, Indonesia: RajaGrafindo Persada, 2001.

[2] P. M. Marzuki, Penelitian hukum . Jakarta, Indonesia: Kencana, 2016.

[3] Jazim. et. al Hamidi, Teori Dan Politik Hukum Tata Negara. Yogyakarta: Total Media, 2008.

[4] F. Umam, Kala Beragama Tak Lagi Merdeka: Majelis Ulama Indonesia Dalam Praksis Kebebasan Beragama. Jakarta, Indonesia: Prenada Media Group, 2015.

[5] S. Naihasy, Kebijakan Publik (Public Policy) Menggapai Masyarakat Madani. Yogyakarta: Mida Pustaka, 2006.

[6] W. Parsons, Public Policy - Pengantar Teori Dan Praktik Analisis Kebijakan (tr). Jakarta: Kencana, 2006.

[7] Edy. et. al Wibowo, Hukum Dan Kebijakan Publik. Yogyakarta: YPAPI, 2004.

[8] Y. W. Harimurti, Kelembagaan Negara Dalam Praktek Ketatanegaraan Indonesia. Malang, Indonesia: Inteligensia Media, 2019. 